\title{
Cyclovirobuxine D inhibits cell proliferation and migration and induces apoptosis in human glioblastoma multiforme and low-grade glioma
}

\author{
LINGQI ZHOU ${ }^{1}$, HAI TANG ${ }^{2}$, FANG WANG ${ }^{3}$, SHANSHAN OU $^{1}$, TONG WU ${ }^{1}$, \\ YINCHAO FANG ${ }^{1}$, JIE XU ${ }^{1}$ and KAIHUA GUO ${ }^{1}$ \\ ${ }^{1}$ Department of Anatomy and Neurobiology, Guangdong Province Key Laboratory of Brain Function and Disease, \\ Zhongshan School of Medicine, Sun Yat-sen University, Guangzhou, Guangdong 510080; \\ ${ }^{2}$ Guangdong Jiangmen Chinese Medical College, Jiangmen, Guangdong 529000; ${ }^{3}$ Department of Molecular Diagnostics, \\ Sun Yat-sen University Cancer Center, Guangzhou, Guangdong 510060, P.R. China
}

Received July 11, 2019; Accepted December 9, 2019

DOI: $10.3892 /$ or.2020.7459

\begin{abstract}
Gliomas are the most common neoplasm of the human central nervous system. Glioblastoma multiforme (GBM) is one of the most serious types of gliomas. Although considerable progress has been made in the development of cancer therapeutic agents, several antineoplastic drugs fail to penetrate the blood-brain barrier (BBB), resulting in a low survival rate of glioma patients. Recent studies have revealed that the traditional Chinese medicine Buxus microphylla contains the main active component Cyclovirobuxine D (CVB-D), which can cross the BBB with a novel delivery system. However, it remains unclear whether CVB-D exerts anticancer effects against GBM and low-grade glioma (LGG). The aim of the present study was to explore the feasibility of CVB-D as a new effective agent in the treatment of GBM and LGG. The ability of CVB-D to inhibit GBM and LGG cell proliferation was detected by CCK8 assay. Flow cytometry was used to detect cell cycle progression and apoptosis induction by Annexin V-FITC/PI assay. The expression levels of the apoptosis-associated proteins, namely cleaved caspase-3 and $\mathrm{Bax} / \mathrm{Bcl}-2$, were detected by western blot analysis. The mitochondrial membrane potential $(\Delta \Psi \mathrm{m})$ was detected by Rh123 dyed fluorescence micrograph. Hoechst staining was used to observe the morphological characteristics of the apoptotic cells. The scratch test was used to evaluate the migration of GBM and LGG cells. The results indicated
\end{abstract}

Correspondence to: Professor Jie Xu or Professor Kaihua Guo, Department of Anatomy and Neurobiology, Zhongshan School of Medicine, Sun Yat-sen University, 74 2nd Zhongshan Road, Guangzhou, Guangdong 510080, P.R. China

E-mail: xujie@mail.sysu.edu.cn

E-mail: guokh@mail.sysu.edu.cn

Keywords: Cyclovirobuxine D, glioma, apoptosis, cell cycle, migration, proliferation, traditional Chinese medicine that CVB-D reduced cell viability of T98G and Hs683 cells. Flow cytometry demonstrated that CVB-D-treated cells were arrested at the $\mathrm{S}$ phase of their cell cycle. The expression levels of the apoptosis-associated proteins were increased in CVB-D-treated cells. Rh123 and Hoechst staining indicated morphological changes and mitochondrial membrane potential changes of the cells undergoing apoptosis. The data confirmed that CVB-D inhibited cell proliferation by arresting the cell cycle of GBM and LLG cells and that it promoted the induction of cell apoptosis by altering the mitochondrial membrane potential. The findings of the present study indicate the potential value of CVB-D in the treatment of glioma.

\section{Introduction}

Gliomas are the most common neoplasm of the central nervous system in humans. Glioblastoma multiforme (GBM) is one of the most serious types of gliomas. Although significant progress has been made in the development of novel therapies for the treatment of this disease, the survival rate of glioma patients remains considerably low. The median survival time in patients with newly diagnosed GBM is frequently less than 15 months (1,2). Approximately 77,000 new glioblastoma cases are diagnosed annually in the United States and Europe (3). The 5-year survival rate of patients is $\sim 5 \%$ (4). Despite maximal tumor resection, high-dose radiation and temozolomide (TMZ) chemotherapy that are currently used in clinical treatment, the prognosis of GBM has not improved significantly. The majority of low-grade glioma (LGG) cases will develop into GBM with conventional therapy. Therefore, it is urgent to explore a new effective and feasible treatment for GBM and LGG.

Cyclovirobuxine D (CVB-D) is the main active component of the traditional Chinese medicine Buxus microphylla and has demonstrated a definitive therapeutic effect on various cardiovascular diseases $(5,6)$. The mechanism of action of CVB-D has been recently studied (7-13). CVB-D [molecular formula: C26-H46-N2-O; molecular weight: 402.662; chemical name: 9,19-cyclopregnan-16-ol,4,4,14-trimethyl-3,20-bis(methylamino)-, $(3 \beta, 5 \alpha, 16 \alpha, 20 \mathrm{~S})-]$ is a triterpenoid alkaloid (Fig. 1) extracted 
from the traditional Chinese medicine Buxus microphylla. This extract has also been investigated for its antitumor effect against breast cancer (13). It is interesting to note that CVB-D can cross the blood-brain barrier (BBB), suggesting that it can have higher efficacy against GBM and LGG treatment than other anti-cancer compounds (14). However, whether and how CVB-D affects GBM and LGG growth remains unknown. In view of these findings, the aim of the present study was to investigate the effects of CVB-D on human GBM and LGG cells.

\section{Materials and methods}

Materials. CVB-D $\left(\mathrm{C}_{26} \mathrm{H}_{46} \mathrm{~N}_{2} \mathrm{O}, \mathrm{FW}\right.$ 402.66, purity 66; YuanYe Biotechnology Co., Ltd.), the Rhodamine 123 (Rh123) kit (BB-41051-1), the Annexin V-FITC/PI apoptosis test kit (BB-4101-2) and the cell cycle test kit (BB-4104-2) were purchased from Shanghai BestBio Biotechnology Co., Ltd. Cell Counting Kit-8 (CCK-8) was purchased from Dojindo Molecular Technologies, Inc. Fetal bovine serum (100 kU/l) and penicillin and streptomycin $(100 \mathrm{mg} / \mathrm{l})$ were purchased from Gibco-BRL Invitrogen; Thermo Fisher Scientific, Inc. The BCA Protein Assay Kit (P0010), and the reagent kits for the protein measurements were purchased from Beyotime Institute of Biotechnology. Bax (cat no. ab69643), Bcl-2 (cat. no. ab32124), caspase-3 (cat. no. ab32351) and cleaved caspase-3 (cat. no. 9664S), beta-actin (cat. no. 4970S) antibodies were purchased from Cell Signaling Technology and Abcam, Inc. Horseradish peroxidase-conjugated anti-rabbit (cat. no. ab44171) and anti-mouse (cat. no. ab21172) antibodies were obtained from Bioworld Technology, Inc. Immobilon western chemiluminescent HRP Substrate and PVDF membranes were obtained from EMD Millipore. The Hoechst 33342 staining kit (C1028) was purchased from Beyotime Institute of Biotechnology.

Cell culture and cell lines. The GBM cell line T98G and the LGG cell line Hs683 were obtained from ATCC. The cells were cultured in high glucose DMEM medium (Gibco; Thermo Fisher Scientific, Inc.) supplemented with $10 \%$ fetal bovine serum (FBS; Gibco; Thermo Fisher Scientific, Inc.) at $37^{\circ} \mathrm{C}$ under an atmosphere of $5 \% \mathrm{CO}_{2}$ and $95 \%$ air. In addition, high glucose DMEM supplemented with $2 \%$ FBS was used in the scratch testing. The medium (half of the total volume) was changed every 3 days during the culture period.

Cell viability assay and colony formation ability. Cell proliferation of T98G and Hs683 cells was monitored by CCK- 8 assay. The cells were plated in a 96-well plate at a concentration of $1 \times 10^{6}$ cells $/ \mathrm{ml}$. The cells were pretreated with various concentrations of CVB-D $(0,15,30,60,120$ and $240 \mu \mathrm{mol} / \mathrm{l})$ for 24,48 and $72 \mathrm{~h}$. Almost all cells reduced cell viability when treated with $240 \mu \mathrm{mol} / \mathrm{l}$ for $72 \mathrm{~h}$, which was the highest concentration and longest time-scale threshold in the experiment. Each group included 6 replicates and was assessed in 3 different experiments. The 96 -well plate was washed with PBS $(0.01 \mathrm{M})$ and $90 \mu \mathrm{l}$ of serum-free medium was mixed with $10 \mu \mathrm{l}$ CCK- 8 solution and added to the wells. The plate was incubated at $37^{\circ} \mathrm{C}$ without light. Following incubation for 1-2 $\mathrm{h}$, the absorbance was monitored at $450 \mathrm{~nm}$ using a

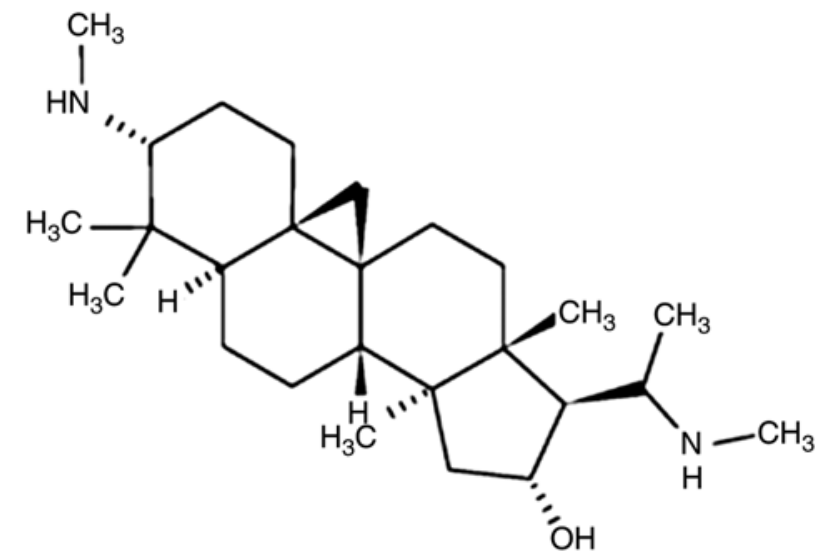

Figure 1. Chemical structure of CVB-D. CVB-D, Cyclovirobuxine D.

microplate reader (Tecan Group, Ltd.). The colony formation ability of T98G and Hs683 cells was analyzed following CVB-D treatment $(0,5,10,20,40$ and $80 \mu \mathrm{mol} / \mathrm{l})$. It was determined that few cells floated when treated with $80 \mu \mathrm{mol} / 1$, which the highest threshold concentration for $24 \mathrm{~h}$, and had no effect on colony formation results. The cells were plated in 6-well plates with 500 cells/well. The cells were pretreated with various concentrations of CVB-D $(0,5,10,20,40$ and $80 \mu \mathrm{mol} / \mathrm{l})$ for $24 \mathrm{~h}$. Subsequently, the medium was changed in the culture for the next 10 days. Finally, the cells were permeabilized with $4 \%$ polyformaldehyde $(10 \mathrm{~min}$ at room temperature) and stained with crystal violet (10 min, at room temperature, $0.05 \%$ w/v). The software GraphPad Prism 8 (GraphPad Software, Inc.) was used to perform statistical analysis of cell viability results.

Capture of mitochondrial membrane potential (MMP or $\Delta \Psi \mathrm{m})$. MMP was assessed using fluorescent Rh123 dye using 6 different concentrations of CVB-D $(0,40,80,120,160$ and $200 \mu \mathrm{mol} / \mathrm{l}$ ) for $6 \mathrm{~h}$. Few cells floated and an evident trend was captured when cells were treated with $200 \mu \mathrm{mol} / \mathrm{l} \mathrm{CVB}-\mathrm{D}$ for $6 \mathrm{~h}$, thus, this was determined as our highest concentration and time-scale threshold for the Rh123 staining experiment. Rh123 was added to the cultures according to the manufacturer's instructions. The images were captured by a flow cytometry (Beckman Coulter). The change in low staining of FITC $^{+}$cells corresponded to the MMP change of the cells. The software GraphPad Prism 8 was used to perform statistical analysis of the results.

Hoechst staining. A total of 6 different concentrations CVB-D $(0,40,80,120,160$ and $200 \mu \mathrm{mol} / \mathrm{l})$ were added to the cells in 6 -well plates for $6 \mathrm{~h}$. Few cells floated and an evident trend was captured when cells were treated with $200 \mu \mathrm{mol} / \mathrm{l} \mathrm{CVB}-\mathrm{D}$ for $6 \mathrm{~h}$, thus, this was determined as our highest concentration and time-scale threshold for the Hoechst 33342 staining experiment. Hoechst 33342 was added to the cultures according to the manufacturer's instructions. The images were captured by a fluorescent microscope (Zeiss $\mathrm{GmbH}$ ). The change in brightness corresponded to the percentage of apoptotic cells. The software Image-Pro Plus 6.0 (Media Cybernetics, Inc.) was used to measure the mean fluorescence intensity (MFI) of figures. 


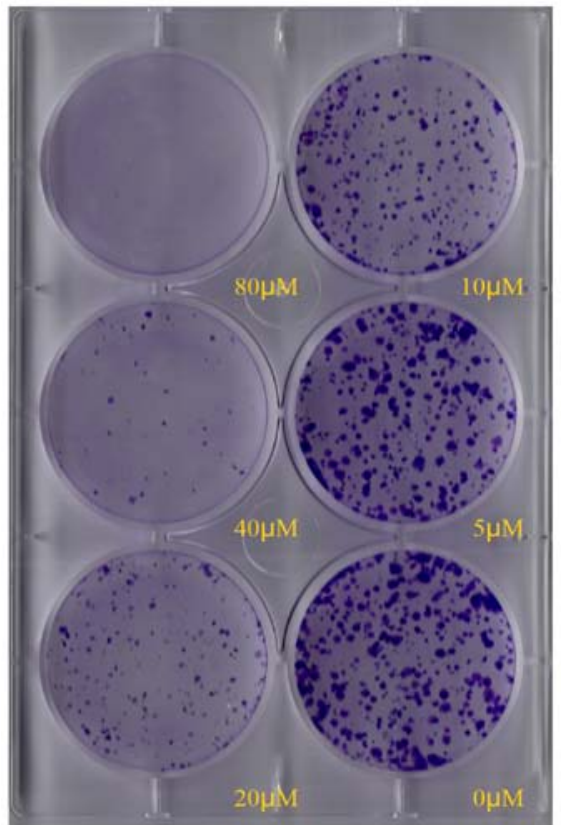

T98G

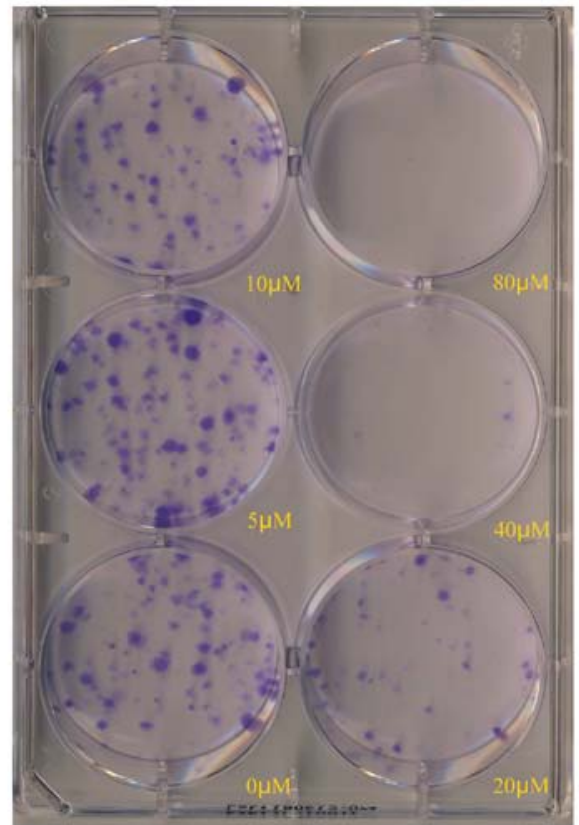

Hs683

Figure 2. Colony formation abilities of T98G and Hs683 cells treated with CVB-D. CVB-D, Cyclovirobuxine D.

Scratch testing. A total of 6 different concentrations CVB-D $(0,20,40,60,80$ and $100 \mu \mathrm{mol} / 1)$ were added to the cells in a 6 -well plate with $2 \%$ FBS-DMEM culture medium for $12 \mathrm{~h}$ after the scratch wound was made. Few cells float and an evident trend was captured when cells were treated with $100 \mu \mathrm{mol} / \mathrm{l} \mathrm{CVB}-\mathrm{D}$ for $12 \mathrm{~h}$, thus, this was determined as the highest concentration and time-scale threshold for the scratch experiment. A high concentration and a long culture duration increase the number of cells floating which affects the experimental results. Subsequently, the images were captured by a bright field view of the microscope (Zeiss $\mathrm{GmbH}$ ). The distances between the the two edges of the scratched cells corresponded to the migration of GBM and LGG cells. The software ImageJ (version 1.50i; National Institutes of Health) was used to do assess the distance between the edges.

Flow cytometric assessment for apoptosis. T98G and Hs683 cells were seeded in 6-well plates and pretreated with 0 , $80,120,160,200$ and $240 \mu \mathrm{mol} / 1 \mathrm{CVB}-\mathrm{D}$ for $24 \mathrm{~h}$. The highest concentration and longest time-scale were determined by cell viability experiment. Cells had $<50 \%$ viability when treated with $240 \mu \mathrm{mol} / \mathrm{l} \mathrm{CVB}-\mathrm{D}$ for $24 \mathrm{~h}$ and an evident trend of apoptosis was captured. The induction of apoptosis was assessed by Annexin V-FITC/PI apoptosis test. The cell cycle analysis was performed by seeding cells in a 6 -well plate and pretreating them with $0,80,160$ and $240 \mu \mathrm{mol} / 1 \mathrm{CVB}-\mathrm{D}$ for $24 \mathrm{~h}$. The highest concentration and longest time-scale were determined by cell viability experiment. Cell had $<50 \%$ viability when treated with $240 \mu \mathrm{mol} / \mathrm{l} \mathrm{CVB}-\mathrm{D}$ for $24 \mathrm{~h}$ and evident trend of the cell cycle was captured. The two tests were carried out in accordance with the manufacturer's instructions. The ModFit software (version 4.1) was used for cell cycle analysis. The CytExpert software (version 2.0) was used for detection of apoptosis and cell cycle progression. The software GraphPad Prism 8 was used to perform statistical analysis of the results.
Western blot analysis. All cells were subcultured in 6-well plates. The cells were incubated initially for $24 \mathrm{~h}$ and subsequently treated with $0,50,100$ and $200 \mu \mathrm{mol} / \mathrm{l}$ CVB-D for an additional $24 \mathrm{~h}$. Since cell lysis had evident reduced protein collection when treated with $240 \mu \mathrm{mol} / \mathrm{l} \mathrm{CVB}-\mathrm{D}$ for $24 \mathrm{~h}$, the highest concentration and longest time-scale was determined as $200 \mu \mathrm{mol} / 1$. The concentration ratio 2:1 was used for grouping and an obvious trend was captured in the western blot experiment. The cells were subsequently washed with ice-cold PBS and lysed in RIPA buffer with 1X PMSF (Beyotime Institute of Biotechnology). The protein concentration was measured with the BCA method. SDS-polyacrylamide gels (10\%) were used for electrophoresis. Following electrophoresis, the proteins were transferred to PVDF membranes and blocked in 5\% skimmed milk in TBST for $1 \mathrm{~h}$. The membranes were probed with primary antibodies for $\beta$-actin, Bax, Bcl-2, caspase-3 and cleaved caspase-3 (all 1:1,000; all from Cell Signaling Technology, Inc.) at $4^{\circ} \mathrm{C}$ overnight. The membranes were subsequently washed and incubated with secondary antibodies for $1 \mathrm{~h}$ [1:10,000, goat anti-mouse IgG $(\mathrm{H}+\mathrm{L}) \mathrm{HRP}$, product code ab21172; 1:10,000, goat anti-rabbit IgG $(\mathrm{H}+\mathrm{L}) \mathrm{HRP}$, product code ab44171] according to the source of primary antibodies. The membranes were subsequently visualized by chemiluminescent ECL reagent (EMD Millipore). The software ImageJ (version 1.50i) was used for densitometric analysis of protein expression and statistical analysis by SPSS 22 software (IBM Corp.).

Statistical analysis. The unpaired Student's t-test was used to determine the differences between the two groups. The data were presented as the mean \pm standard error of mean (SEM). One way ANOVA followed by Bonferroni's post hoc test were used to perform multi-group data comparisons using GraphPad Prism 8 and SPSS 22 software. $\mathrm{P}<0.05$ was used to indicate a statistically significant difference. 

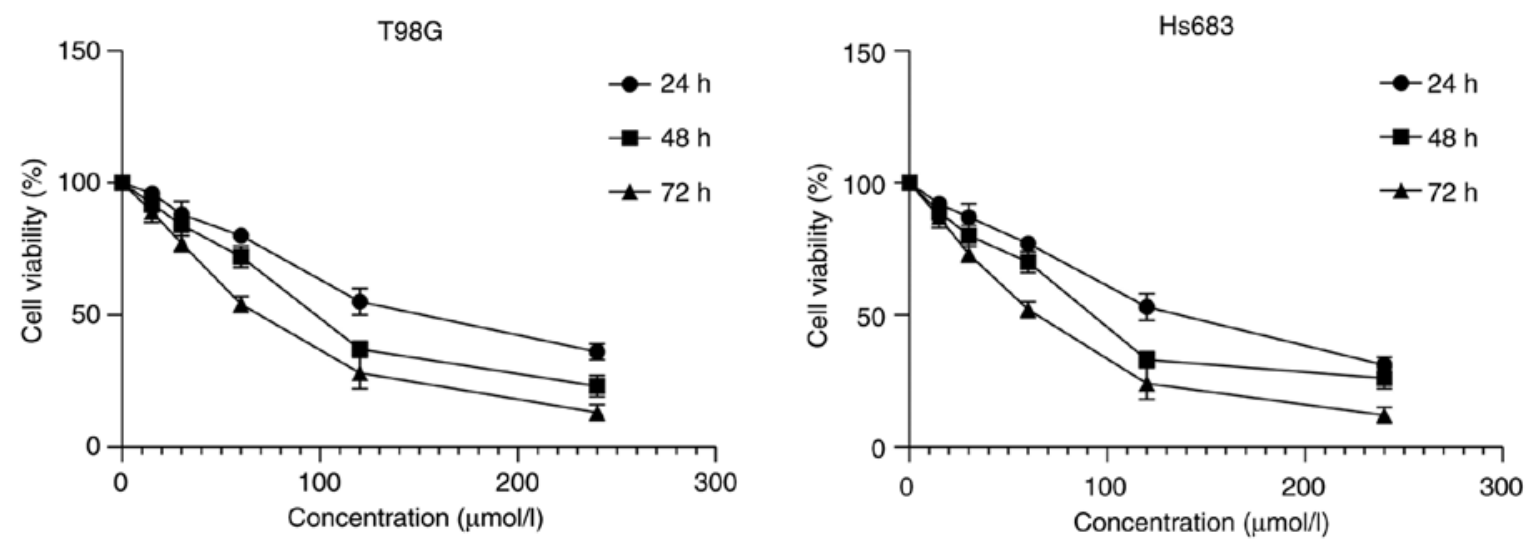

Figure 3. CVB-D reduces cell viability of T98G and Hs683 cells. Each experiment involved three replicates. CVB-D, Cyclovirobuxine D.

A
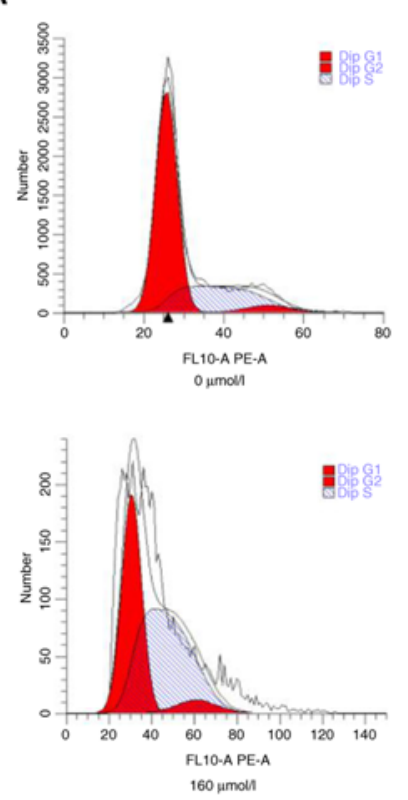

$B$

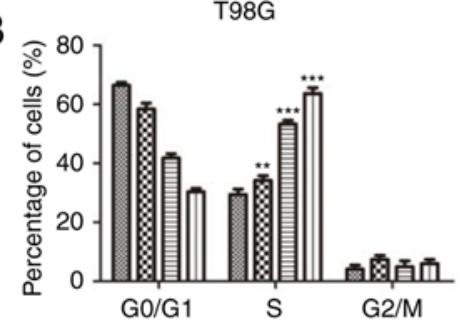

Cell cycle of T98G
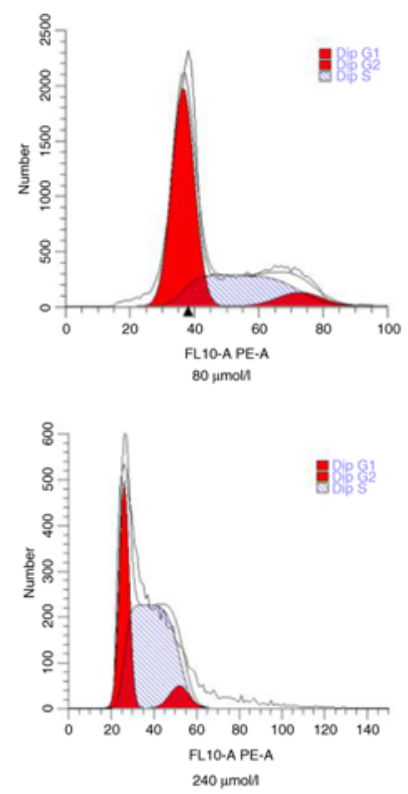

240 umol

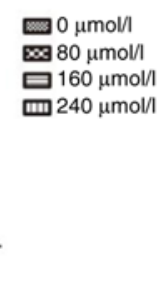

Cell cycle of $\mathrm{Hs} 683$
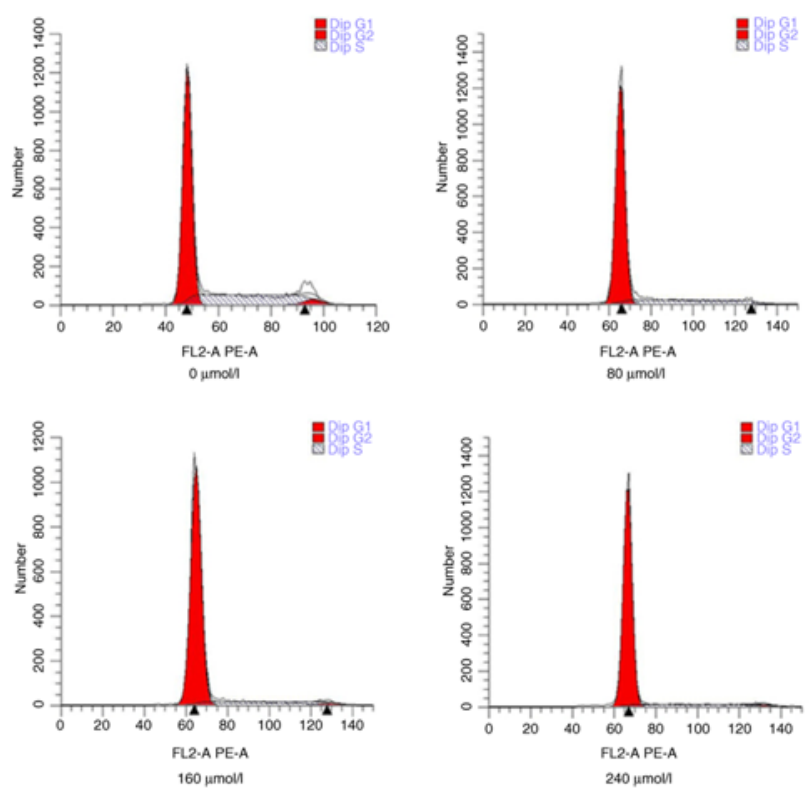

Hs683

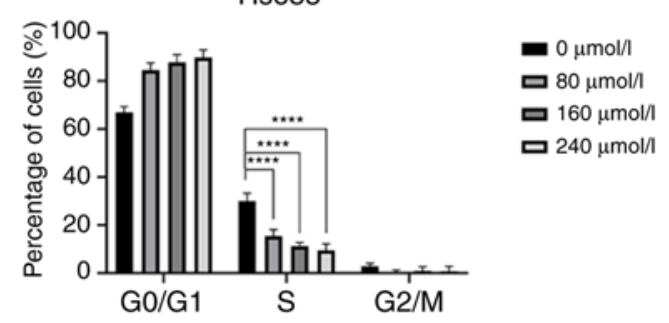

Figure 4. Cell cycle of CVB-D-treated glioma cells. (A) Cell cycle analysis of CVB-D treated T98G and Hs683 cells as detected by flow cytometry $(0,80,160$ and $240 \mu \mathrm{mol} / \mathrm{l}$ ). (B) Statistical analysis of the percentage of cells at the $\mathrm{G}_{0} / \mathrm{G}_{1}, \mathrm{~S}$ and $\mathrm{G}_{2} / \mathrm{M}$ phases of the $\mathrm{T} 98 \mathrm{G}$ and Hs683 cell cycle. Each group was compared with the $0 \mu \mathrm{mol} / 1$ group with regard to the $\mathrm{S}$ phase. ${ }^{* *} \mathrm{P}<0.01,{ }^{* * *} \mathrm{P}<0.001,{ }^{* * * *} \mathrm{P}<0.0001$. CVB-D, Cyclovirobuxine D.

\section{Results}

$C V B-D$ reduces cell viability and colony formation ability of $G B M$ and LGG cells. Crystal violet staining indicated that the number of colonies of CVB-D-treated T98G and Hs683 cells were markedly decreased compared with those noted in untreated cells (Fig. 2). Subsequently, various concentrations of CVB-D were used to treat the cells. Following incubation with $0,15,30,60,120$ and $240 \mu \mathrm{mol} / \mathrm{l} \mathrm{CVB-D}$ for 24,48 and
$72 \mathrm{~h}$, the viability of the cells was assessed using a CCK- 8 kit. The results indicated that the cell viability was reduced in a concentration- and time-dependent manner (Fig. 3). All dosing groups exhibited statistical significant differences compared with the control group (data not shown).

$C V B-D$ arrests cells at the $S$ and $G_{0} / G_{1}$ phase. The cell cycle plays an important role in cancer cell proliferation. Therefore, the cell cycle of CVB-D pretreated GBM cells was assessed by 
A
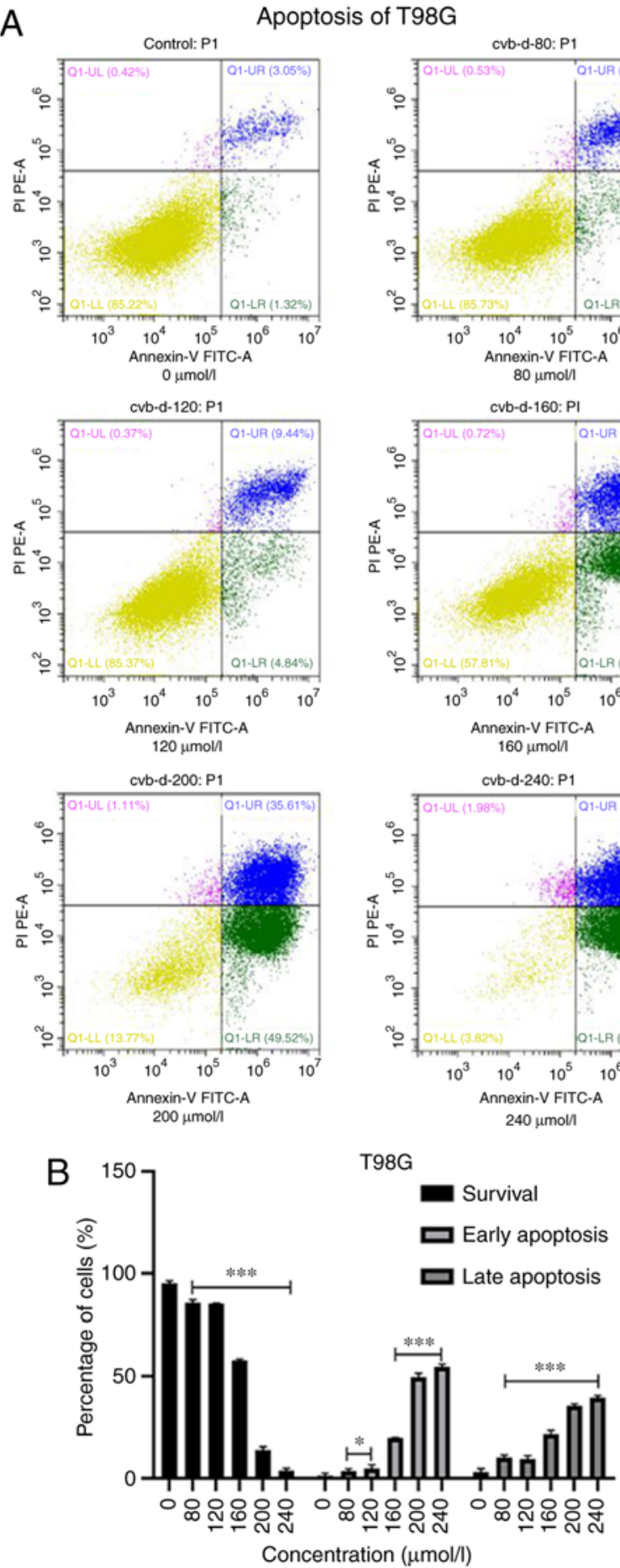

cvb-d-80: P1
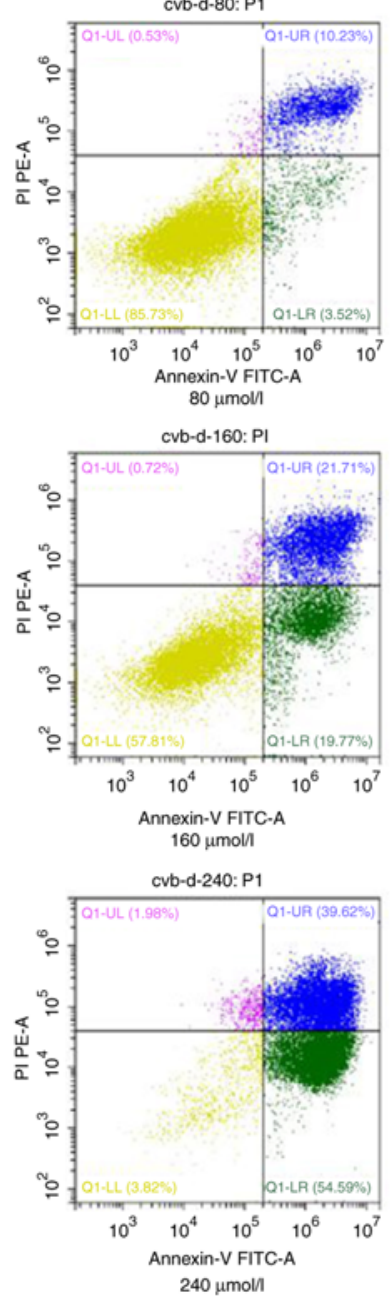

T98G

口 Early apoptosis 


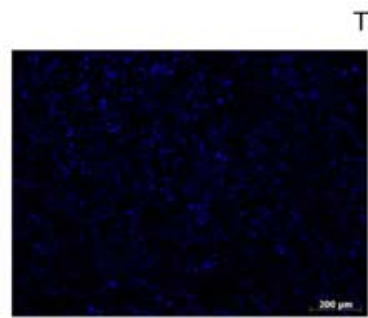

$0 \mu \mathrm{mol} / \mathrm{l}$

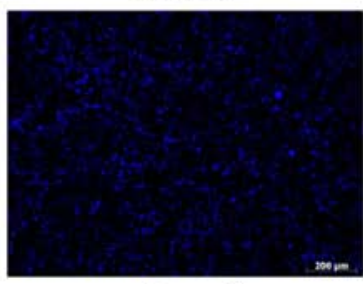

$80 \mu \mathrm{mol} / \mathrm{l}$

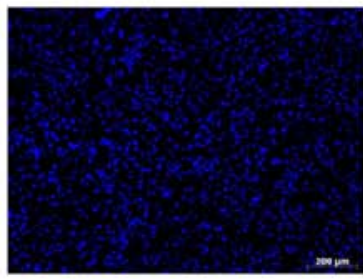

$160 \mu \mathrm{mol} / \mathrm{l}$
T98G

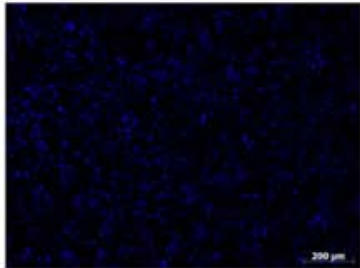

$40 \mu \mathrm{mol} / \mathrm{l}$

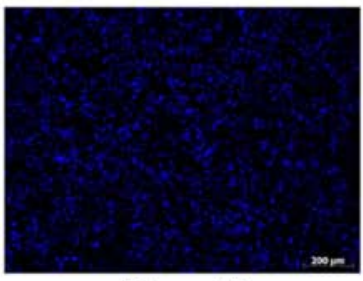

$120 \mu \mathrm{mol} / \mathrm{l}$

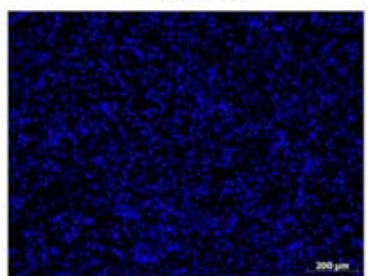

$200 \mu \mathrm{mol} / 1$

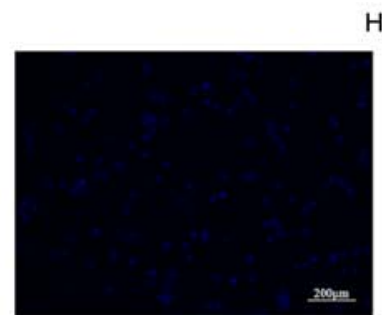

$0 \mu \mathrm{mol} / 1$

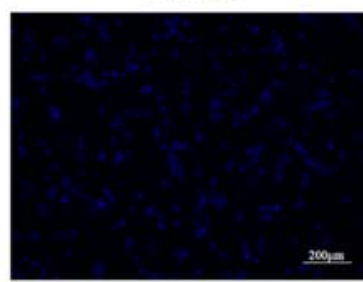

$80 \mu \mathrm{mol} / \mathrm{l}$

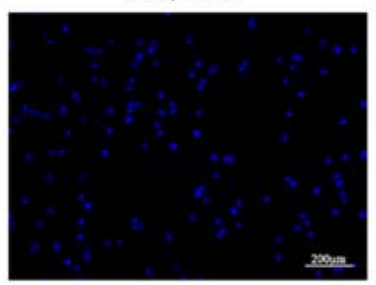

$160 \mu \mathrm{mol} / \mathrm{l}$
Hs683

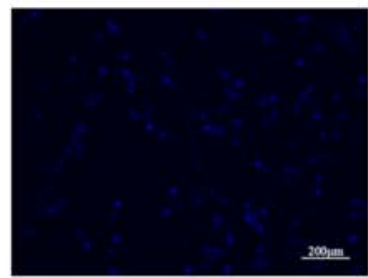

$40 \mu \mathrm{mol} / 1$

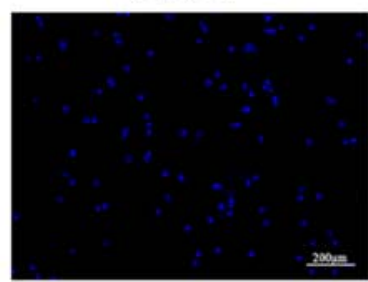

$120 \mu \mathrm{mol} / \mathrm{I}$

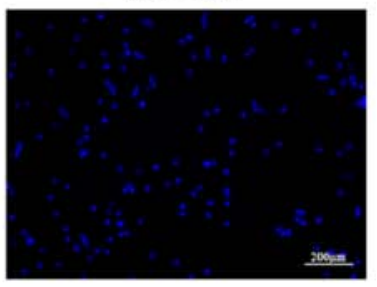

$200 \mu \mathrm{mol} / \mathrm{l}$
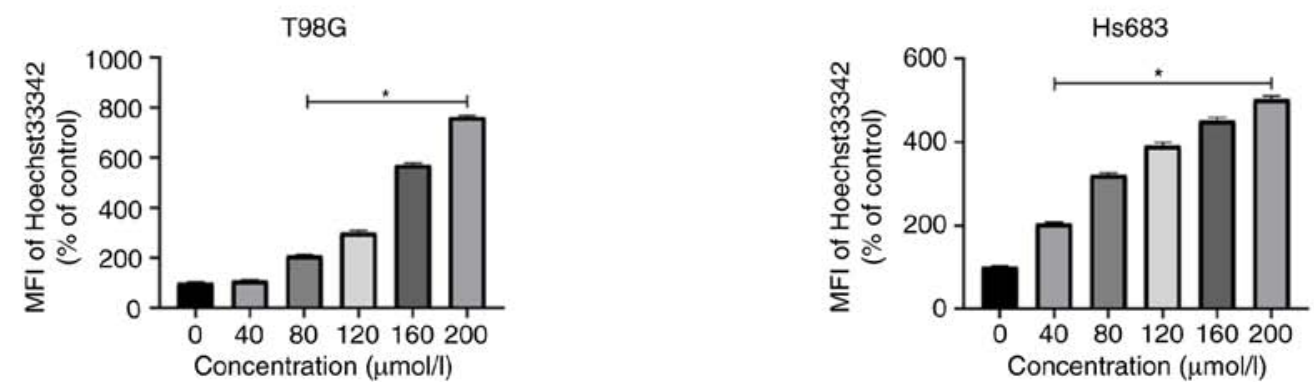

Figure 6. Hoechst staining is used to observe the morphological characteristics of T98G and Hs683 cells. The results indicated that the percentage of hyperchromatic nuclei was increased as the concentration of CVB-D increased. The MFI was assessed by Image-Pro Plus 6.0, and statistically analyzed by GraphPad Prism 8. "P<0.05. CVB-D, Cyclovirobuxine D; MFI, mean fluorescence intensity.

Hoechst staining was used for the observation of the morphological characteristics of the apoptotic GBM and LGG cells. Each Hoechst staining group was monitored by fluorescence microscopy (Fig. 6). Concomitantly, Rh123 staining was used to confirm the induction of cell apoptosis by the mitochondrial-dependent pathway (Fig. 7).

CVB-D significantly inhibits tumor cell migration. Initially, various concentrations of CVB-D $(0,20,40,60,80$ and $100 \mu \mathrm{mol} / \mathrm{l}$ ) were used for $12 \mathrm{~h}$ pretreatment of the cells and cell migration was assessed by light microscopy. The results indicated that CVB-D significantly inhibited tumor cell migration of GBM and LGG cells. Significant differences were noted in all the CVB-D groups compared with the control samples (Fig. 8).

$C V B-D$ induces the expression levels of apoptosis-associated proteins in GBM and LGG cells. The expression levels of the proteins associated with cell apoptosis were examined by western blotting. The results indicated that the expression levels of Bax and cleaved caspase- 3 were increased. In contrast to these findings, the expression levels of caspase-3 and Bcl-2 were decreased in CVB-D-pretreated T98G and Hs683 cells in a concentration-dependent manner. These results indicated that the apoptotic process was regulated by increased expression in the levels of the apoptosis-associated proteins. The ratios of $\mathrm{Bax} / \mathrm{Bcl}-2$ and cleaved caspase- 3 were increased suggesting the induction of apoptosis in T98G and Hs683 cells (Fig. 9).

\section{Discussion}

Human brain glioblastoma is a malignant tumor, which usually recurs from the surgical resection area and is characterized by the tumor infiltration or the transfer of tumor cells along the white matter fiber bundle. The main treatment strategy involves the inhibition of glioblastoma cell migration. Previous studies have revealed that its average incidence rate is $3.19 / 100,000$ in the population, whereas the 5-year survival rate of GBM patients is estimated to $\sim 5 \%(4,15)$. Conventional surgery and radiotherapy/chemotherapy do not effectively prolong the survival of patients with GBM. These patients do not often 


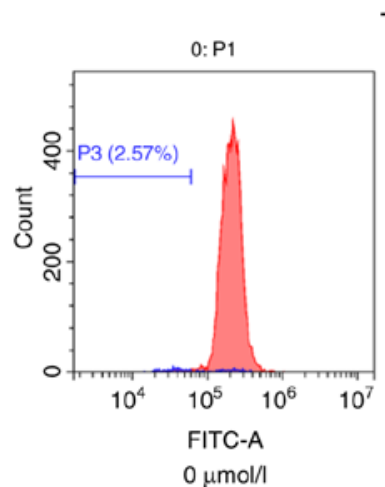

T98G
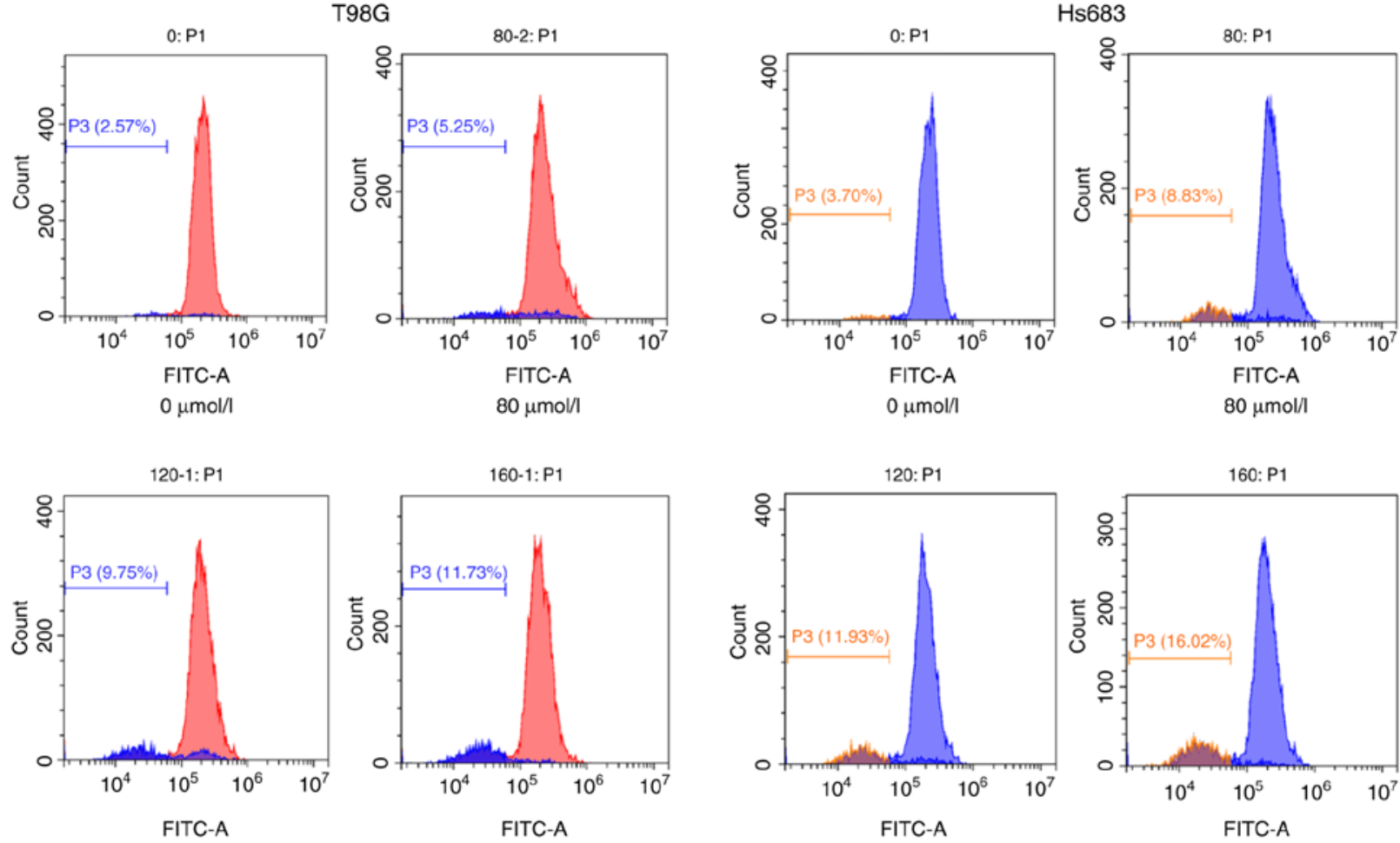

$120 \mu \mathrm{mol} /$

$160 \mu \mathrm{mol} / \mathrm{I}$
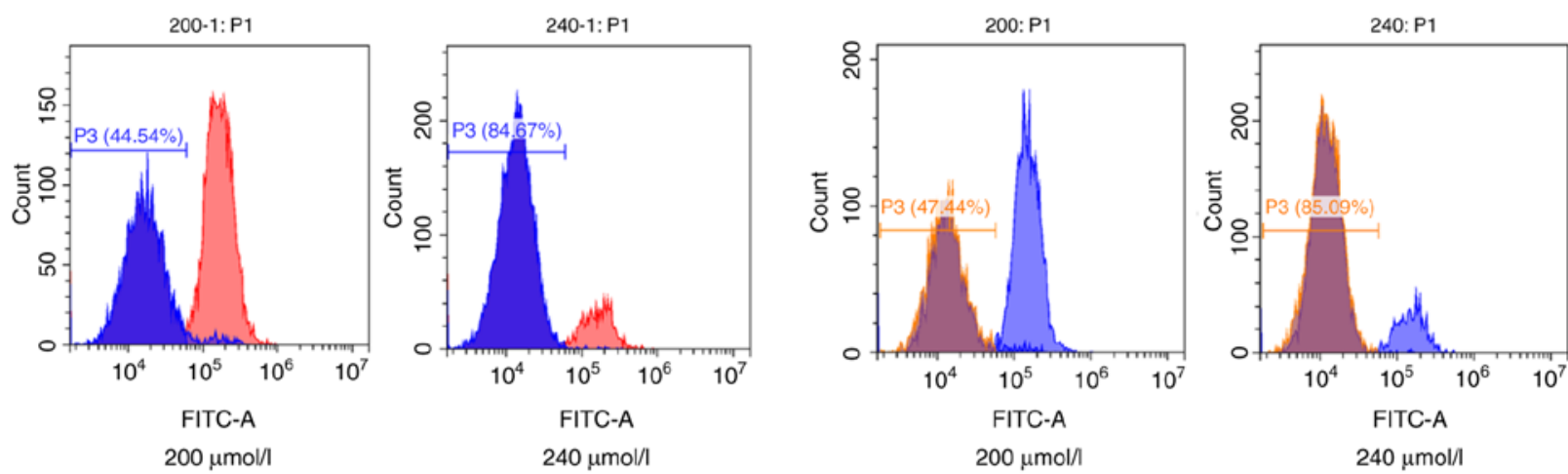

T98G
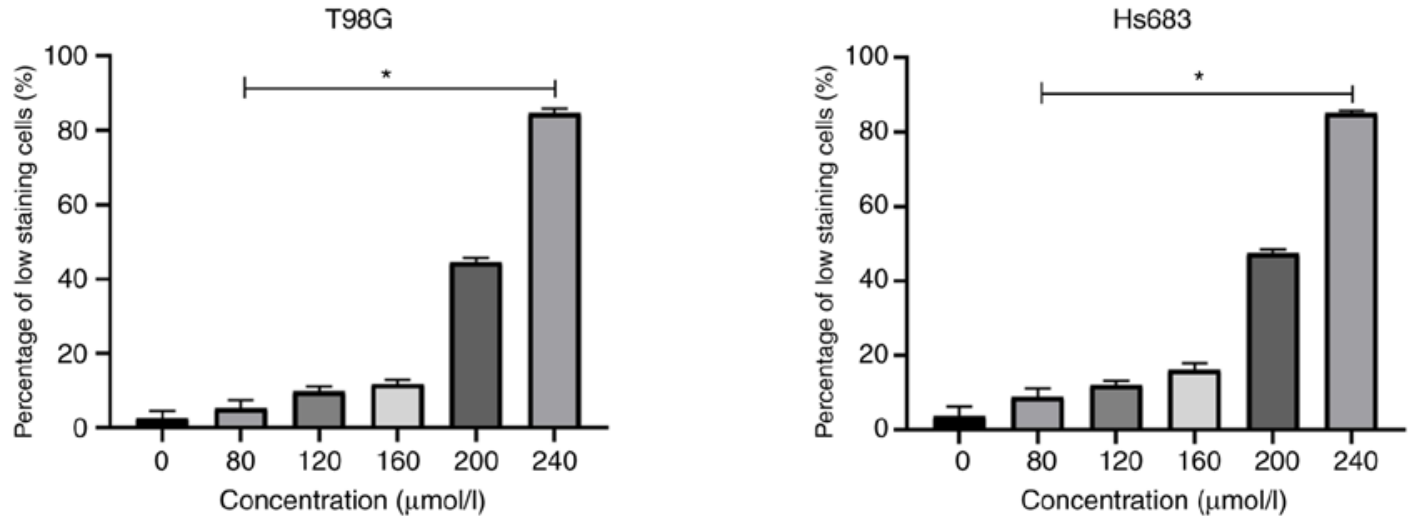

Figure 7. Rh123 staining of T98G and Hs683 cells following various concentrations of CVB-D pretreatment. The staining analysis was performed by flow cytometry. The results indicated that the hyperchromatic cells were increased as the concentration of CVB-D increased. The change in low staining of FITC ${ }^{+}$ cells corresponded to the MMP change of the cells (MMP or $\Delta \Psi \mathrm{m}$ ). Statistical analysis of low staining of FITC ${ }^{+}$cells was performed using SPSS 22 . "P<0.05. CVB-D, Cyclovirobuxine D; Rh123, Rhodamine 123.

survive from postoperative tumor recurrence and their median survival rate is estimated to $\sim 15$ months (15). Therefore, it is important to identify and develop new effective strategies for the treatment of GBM.
CVB-D is the main active component of the traditional Chinese medicine Buxus microphylla, which has been used to treat cardiovascular diseases (12). One of the main obstacles in the treatment of brain tumors is the inability of the 


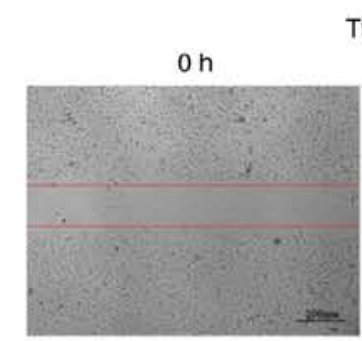

$0 \mu \mathrm{mol} / \mathrm{l}$

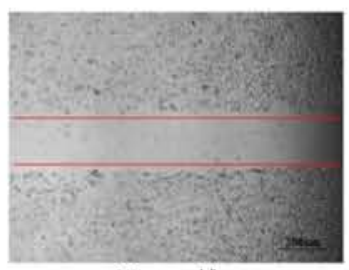

$20 \mu \mathrm{mol} / \mathrm{l}$

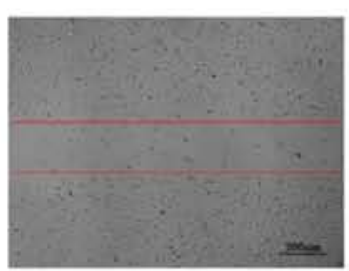

$40 \mu \mathrm{mol} / 1$

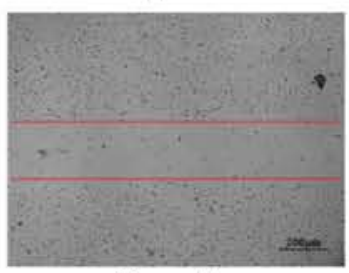

$60 \mu \mathrm{mol} / \mathrm{l}$

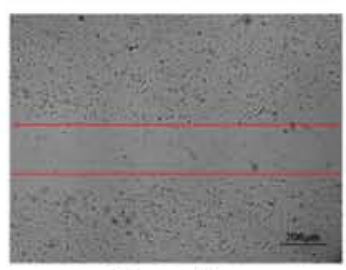

80 umol/

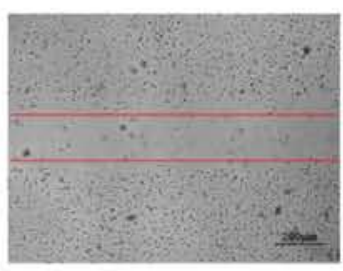

$100 \mu \mathrm{mol} / \mathrm{l}$
$12 \mathrm{~h}$

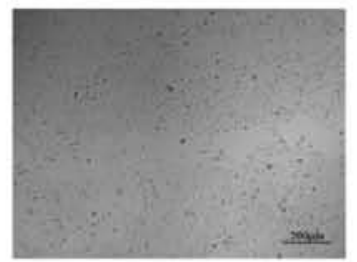

$0 \mu \mathrm{mol} / \mathrm{I}$

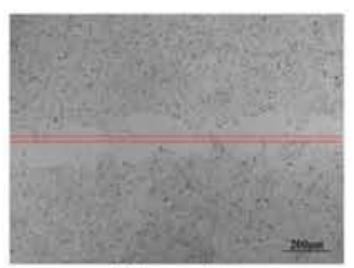

$20 \mu \mathrm{mol} / \mathrm{I}$

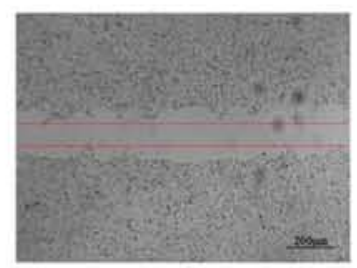

$40 \mu \mathrm{mol} / \mathrm{I}$

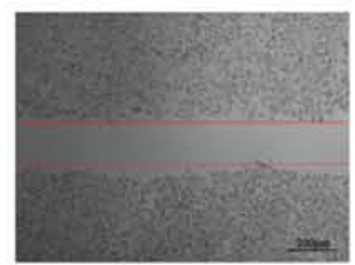

$60 \mu \mathrm{mol} / \mathrm{l}$

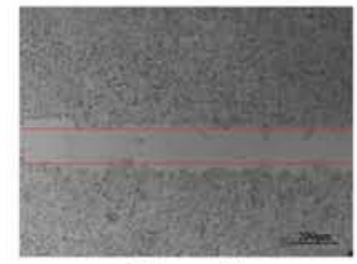

$80 \mu \mathrm{mol} / \mathrm{l}$

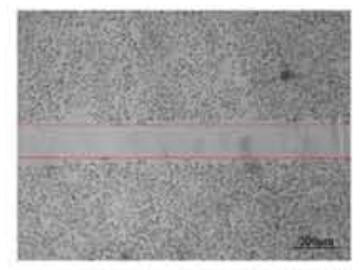

$100 \mu \mathrm{mo} / \mathrm{I}$

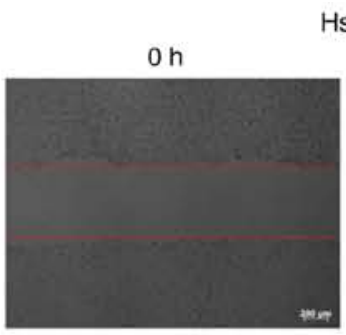

$0 \mu \mathrm{mol} / \mathrm{l}$

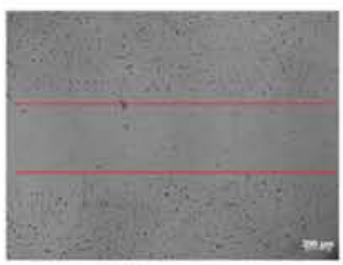

$20 \mu \mathrm{mol} / \mathrm{l}$

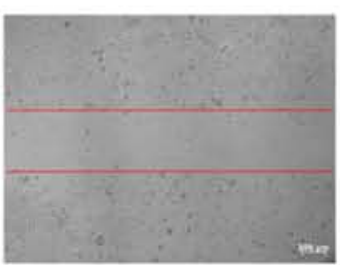

$40 \mu \mathrm{mol} / \mathrm{I}$

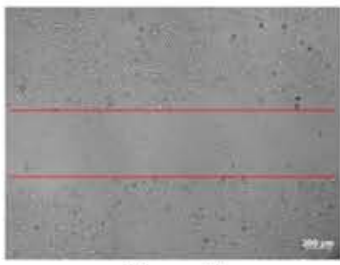

$60 \mu \mathrm{mol} / \mathrm{I}$

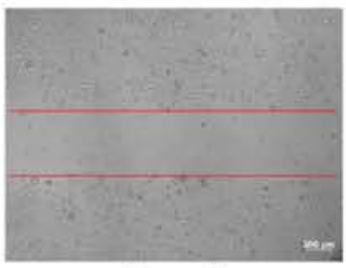

$80 \mu \mathrm{mol} / \mathrm{I}$

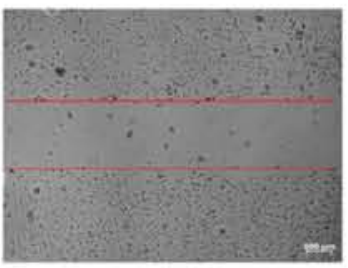

$100 \mu \mathrm{mol} / \mathrm{l}$
Hs683

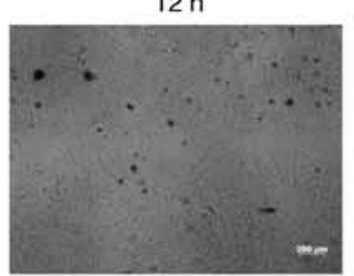

$0 \mu \mathrm{mol} / \mathrm{l}$

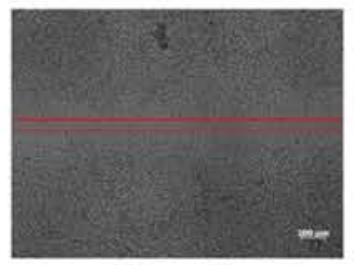

$20 \mu \mathrm{mol} / \mathrm{I}$

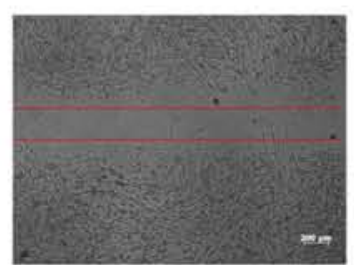

$40 \mu \mathrm{mol} / \mathrm{l}$

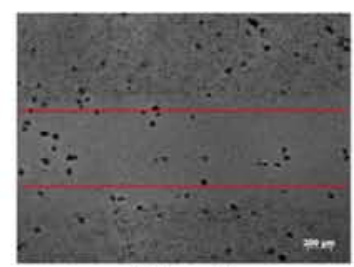

$60 \mu \mathrm{mol} / \mathrm{I}$

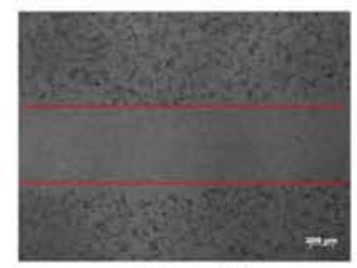

$80 \mu \mathrm{mol} / \mathrm{l}$

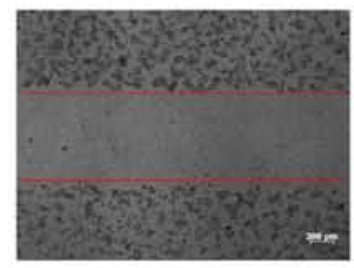

$100 \mu \mathrm{mol} / \mathrm{l}$

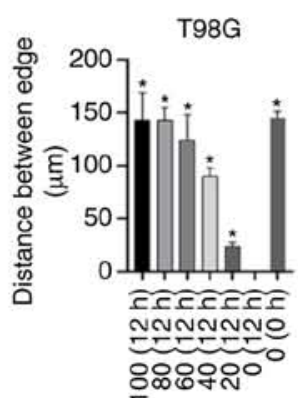

Concentration $(\mu \mathrm{mol} / \mathrm{l})$

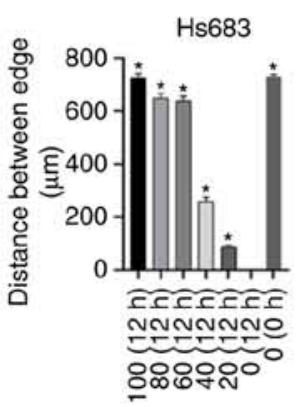

Concentration $(\mu \mathrm{mol} / \mathrm{l})$

Figure 8. Scratch test of T98G and Hs683 cells. The scratch test was conducted at $12 \mathrm{~h}$ and the results indicated that tumor cell migration was significantly inhibited following a concentration increase of CVB-D. Distances between the edges of the cells was analyzed by SPSS 22. "P<0.05. CVB-D, Cyclovirobuxine D. 
T98G
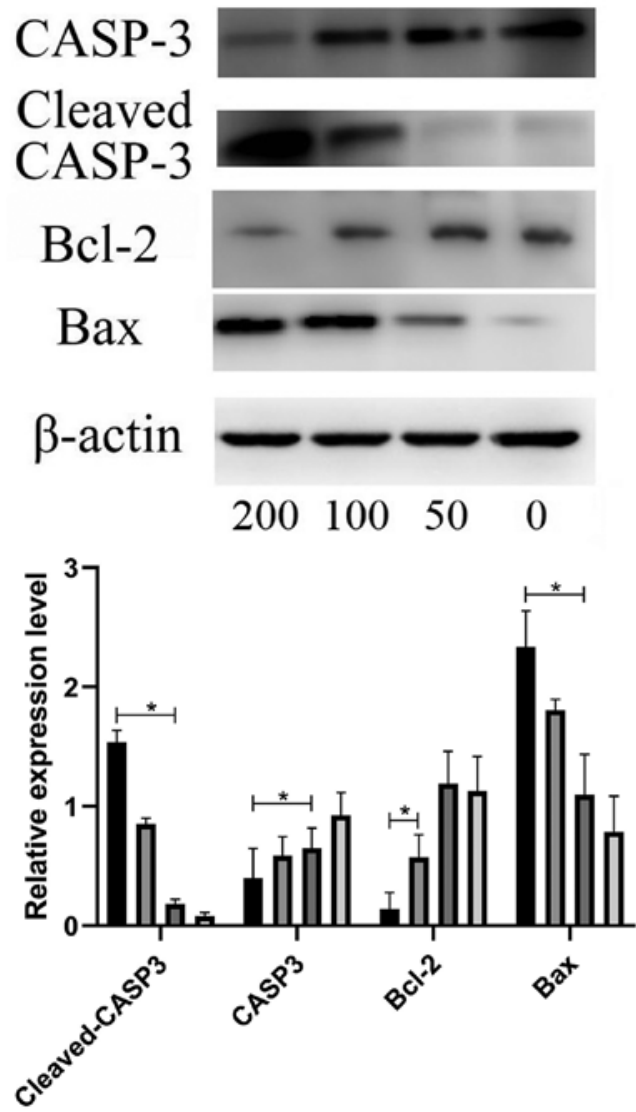

Hs683

CASP-3

Cleaved CASP-3

Bcl-2

Bax

$\beta$-actin

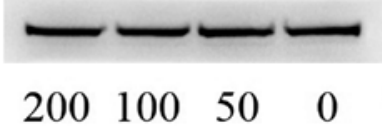

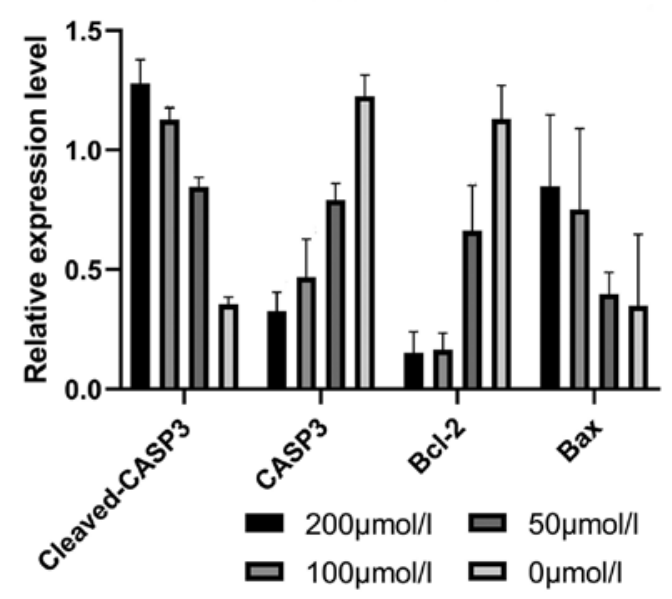

Figure 9. Various concentrations of CVB-D induce the expression of apoptosis-associated proteins in T98G and Hs683 cells. The cells were pretreated with various concentrations of CVB-D for $6 \mathrm{~h}$ and the protein bands were detected by western blotting. $\beta$-actin was used as the control protein. The software ImageJ (version 1.50i) was used for densitometric analysis of the protein expression and statistical analysis was performed using SPSS 22 software. ${ }^{*} \mathrm{P}<0.05$. CVB-D, Cyclovirobuxine D.

chemotherapeutic drugs to cross the BBB. Therefore, although several novel drugs have been successfully applied in the treatment of various types of tumors their efficacy is considerably low in brain tumors, notably in GBM and LGG. The antitumor effect of CVB-D has been investigated in breast and gastric cancers $(13,16)$. However, it is uncertain whether it is effective in the treatment of GBM and LGG. Previous studies have revealed that cell apoptosis can be induced by a variety of drugs and physical and chemical factors (17-19). Moreover, a previous study demonstrated that CVD-B exhibited antitumor effects via the Akt/mTOR pathway (13), whereas it has also been revealed that the Akt/mTOR signaling pathway is associated with various physiological processes including cell growth, proliferation and apoptosis (20-22). A recent study developed a novel drug delivery system for CVB-D, which can in theory enhance the efficacy of CVB-D therapy (14).

CVB-D affects the expression of the family members of cysteine-containing aspartate-specific proteases (caspases), which contain several proteins that play a key role in the cellular process of apoptosis. Caspase-3 is one of the most important members of this protein family, which has been reported to be the key executor of cell apoptosis. Upon activation of caspase enzymes by the external apoptotic signals, the apoptotic cascade is activated. Subsequently, the apoptosis-signaling pathway of the cells is activated by the interaction of caspases with several other proteases. In the present study, it was demonstrated that CVB-D induced apoptosis via upregulation of apoptosis-associated proteins. Future studies may address the investigation of the gene expression profile of CVB-D-induced apoptotic cells.

The data reported in the present study revealed that the GBM and LGG cell migration and cell cycle progression were inhibited following treatment of the cells with a low concentration of CVB-D. This strategy can be applied as a potential adjuvant therapy in GBM or LGG patients that are treated with temozolamide.

In addition, CVB-D could regulate calcium levels inside the cells (23). Previous studies have suggested that calcium levels play an important role in tumor growth, apoptosis and differentiation (24-26). The hypothesis that CVB-D can promote tumor apoptosis by affecting calcium ion channels can be further explored in future studies and can aid the investigation of the antitumor activity of this compound.

The present study, to the best of our knowledge, is the first to reveal the antitumor activity of CVB-D in human GBM and LGG. The results demonstrated that CVB-D inhibited cell proliferation and tumor migration, while it induced apoptosis via the mitochondrial-dependent pathway. CVB-D is a main component of the traditional Chinese medicine Buxus microphylla and exhibits potent antitumor effects against GBM and LGG. This evidence can offer insight in the treatment of this type of disease. 


\section{Acknowledgements}

Not applicable.

\section{Funding}

The present study was supported by the National Natural Science Foundation of China (grant. no. 31360258); Special fund for science and technology development of Guangdong Province (no. 2016A020215036); natural Science Foundation of Guangdong Province (nos. 2015A030313077, 2015A030313047 and 2017A030310192); project of Educational Commission of Guangdong Province (2018GkQNCX085); Science and Technology Program of Jiangmen (2019E021).

\section{Availability of data and materials}

The datasets used and/or analyzed during the current study are available from the corresponding author on reasonable request.

\section{Authors' contributions}

LZ, KG and JX designed the study. LZ performed the experiments and HT wrote the manuscript. HT, FW, SO, TW, YF helped to performed the experiments and collected the data, HT and FW participated in the statistical analysis. All authors read and approved the final manuscript. All authors have read and approved the final manuscript and agree to be accountable for all aspects of the research in ensuring that the accuracy or integrity of any part of the work are appropriately investigated and resolved.

\section{Ethics approval and consent to participate}

Not applicable.

\section{Patient consent for publication}

Not applicable.

\section{Competing interests}

The authors declare that they have no competing interests.

\section{References}

1. Imperato JP, Paleologos NA and Vick NA: Effects of treatment on long-term survivors with malignant astrocytomas. Ann Neurol 28: 818-822, 1990.

2. Stupp R, Mason WP, van den Bent MJ, Weller M, Fisher B, Taphoorn MJ, Belanger K, Brandes AA, Marosi C, Bogdahn U, et al: Radiotherapy plus concomitant and adjuvant temozolomide for glioblastoma. N Engl J Med 352: 987-996, 2005

3. Ashok AR, Pouratian N, Sherman J, Ahmed G and Shaffrey ME. Advances in brain tumor surgery. Neurol Clin 25: 975-1003, 2007.

4. Shan P, Mao RB, Xu JM and Li JX: The beneficial effects of cyclovirobuxine D (CVBD) in coronary heart disease. A double blind analysis of 110 cases. J Tradit Chin Med 4: 15-19, 1984.

5. Grossini E, Battaqlia A, Brunelleschi S, Mary DA, Molinari C, Viano I and Vacca G: Coronary effects of cyclovirobuxine D in anesthetized pigs and in isolated porcine coronary arteries. Life Sci 65: 59-65, 1999.

6. Yu B, Fang TH, Lü GH, Xu HQ and Lu JF: Beneficial effect of cyclovirobuxine $\mathrm{D}$ on heart failure rats following myocardial infarction. Fitoterapia 82: 868-877, 2011.
7. Grossini E, Avanzi G, Gallicchio M, Molinari C, Vacca G and Bellomo G: Regulation of $\mathrm{Ca}^{2+}$ Movements by cyclovirobuxine $\mathrm{D}$ in ECV304 endothelial cells. Pharmacol Res 52: 154-161, 2005.

8. Chen QW, Shan HL, Sun HL, Wang H and Yang BF: Effects of cyclovirobuxine D on intracellular $\mathrm{Ca}^{2+}$ and $\mathrm{L}$-type $\mathrm{Ca}^{2+}$ current in rat ventricular cardiomyocytes. Yao Xue Xue Bao 39: 500-503, 2004 (In Chinese)

9. Hu D, Liu X, Wang Y and Chen S: Cyclovirobuxine D ameliorates acute myocardial ischemia by K(ATP)channel opening, nitric oxide release and anti-thrombosis. Eur J Pharmacol 569: 103-109, 2007.

10. Yue Y, Liu R, Liu J, Dong Q and Fan J: Experimental and theoretical investigation on the interaction between cyclovirobuxine $\mathrm{D}$ and human serum albumin. Spectrochim Acta A Mol. Biomol. Spectrosc 128: 552-558, 2014.

11. Guo Q, Guo J, Yang R, Peng H, Zhao J, Li L and Peng S: Cyclovirobuxine D attenuates doxorubicin-induced cardiomyopathy by suppression of oxidative damage and mitochondrial biogenesis impairment. Oxid Med Cell Longev 2015: 151972, 2015.

12. Lu J, Sun D, Gao S, Gao Y, Ye J and Liu P: Cyclovirobuxine D induces autophagy-associated cell death via the Akt/mTOR pathway in MCF-7 human breast cancer cells. J Pharmacol Sci 125: 74-82, 2014.

13. Burri SH, Gondi V, Brown PD and Mehta MP: The evolving role of tumor treating fields in managing glioblastoma: Guide for Oncologists. Am J Clin Oncol 41: 191-196, 2018.

14. Thakkar JP, Dolecek TA, Horbinski C, Ostrom QT, Lightner DD, Barnholtz-Sloan JS and Villano JL: Epidemiologic and molecular prognostic review of glioblastoma. Cancer Epidemiol Biomarkers Prev 23: 1985-1996, 2014.

15. Wu J, Tan Z, Chen J and Dong C: Cyclovirobuxine D inhibits cell proliferation and induces mitochondria-mediated apoptosis in human gastric cancer cells. Molecules 20: 20659-20668, 2015.

16. Zhao W, Li X, Wang J, Wang C, Jia Y, Yuan S, Huang Y, Shi Y and Tong Z: Decreasing eukaryotic initiation factor 3C (EIF3C) suppresses proliferation and stimulates apoptosis in breast cancer cell lines through mammalian target of rapamycin (mTOR) pathway. Med Sci Monit 23: 4182-4191, 2017.

17. Lin J, Feng J, Yang H, Yan Z, Li Q, Wei L, Lai Z, Jin Y and Peng J: Scutellaria barbata D. Don inhibits 5-fluorouracil resistance in colorectal cancer by regulating PI3K/AKT pathway. Oncol Rep 38: 2293-2300, 2017.

18. Tan J, Shen W, Shi W, Chen X, Sun D, Xu C, Yan Q, Cheng H, Lai Y and Ji H: ONTD induces growth arrest and apoptosis of human hepatoma Bel-7402 cells though a peroxisome proliferator-activated receptor $\gamma$-dependent pathway. Toxicol In Vitro 45: 44-53, 2017.

19. Chen S, Fisher RC, Sign S, Molina LA, Shenoy AK, Lopez MC, Baker HV, Koomen JM, Chen Y, Gittleman H, et al: Inhibition of PI3K/Akt/mTOR signaling in PI3KR2-overexpressing colon cancer stem cells reduces tumor growth due to apoptosis. Oncotarget 8: 50476-50488, 2016.

20. Amini-Farsani Z, Sangtarash $\mathrm{MH}$, Shamsara $\mathrm{M}$ and Teimori $\mathrm{H}$ : MiR-221/222 promote chemoresistance to cisplatin in ovarian cancer cells by targeting PTEN/PI3K/AKT signaling pathway. Cytotechnology 70: 203-213, 2018.

21. Zahed Panah M, Nikbakht M, Sajjadi SM, Rostami S, Norooznezhad AH, Kamranzadeh Fumani H, Ghavamzadeh A and Mohammadi S: Anti-apoptotic effects of osteopontin via the up-regulation of $\mathrm{AKT} / \mathrm{mTOR} / \beta$-catenin loop in acute myeloid leukemia cells. Int J Hematol Oncol Stem Cell Res 11: 148-157, 2017.

22. Yu B, Ruan M, Zhou L, Xu L and Fang T: Influence of cyclovirobuxine $\mathrm{D}$ on intracellular $\left[\mathrm{Ca}^{2+}\right]$ regulation and the expression of the calcium cycling proteins in rat myocytes. Fitoterapia 83: 1653-1665, 2012.

23. Chen YF, Chen YT, Chiu WT and Shen MR: Remodeling of calcium signaling in tumor progression. J Biomed Sci 20: 23, 2013

24. Stewart TA, Yapa KT and Monteith GR: Altered calcium signaling in cancer cells. Biochim Biophys Acta 1848: 2502-2511, 2015.

25. Macià $\mathrm{A}$, Herreros J, Martí RM and Cantí C: Calcium channel expression and applicability as targeted therapies in melanoma. Biomed Res Int 2015: 587135, 2015.

26. Wei H, Liu T, Jiang N, Zhou K, Yang K, Ning W and Yu Y: A novel delivery system of Cyclovirobuxine $\mathrm{D}$ for brain targeting: Angiopep-conjugated polysorbate 80-coated liposomes via intranasal administration. J Biomed Nanotechnol 14: 1252-1262, 2018.

This work is licensed under a Creative Commons Attribution-NonCommercial-NoDerivatives 4.0 International (CC BY-NC-ND 4.0) License. 